\title{
Miocene-Pliocene ice-volcano interactions at monogenetic volcanoes near Hobbs Coast, Marie Byrd Land, Antarctica
}

\author{
T.I. Wilch ${ }^{1}$ and W.C. McIntosh ${ }^{2}$ \\ ${ }^{1}$ Department of Geological Sciences, Albion College, Albion MI 49224 \\ ${ }^{2}$ Department of Earth and Environmental Science, New Mexico Tech, Socorro NM 87801
}

\begin{abstract}
Paleoenvironmental reconstructions and ${ }^{40} \mathrm{Ar} /{ }^{39} \mathrm{Ar}$ geochronology of seven eroded monogenetic volcanoes near the Hobbs Coast, Marie Byrd Land, West Antarctica provide proxy records of WAIS paleo-ice-levels in MiocenePliocene times. Interpretations, based on lithofacies analysis, indicate whether the volcanoes erupted below, near, or above the level of the ice sheet. Our interpretations differ significantly from previous interpretations as they highlight the abundant evidence for ice-volcano interactions at emergent paleoenvironments but limited evidence of higher-thanpresent syn-eruptive ice-levels. Evidence for subglacial volcanic paleoenvironments is limited to Kennel Peak, a $\sim 8 \mathrm{Ma}$ volcano where a pillow lava sequence extending $25 \mathrm{~m}$ above current ice level overlies an inferred glacial till and unconformity. A major complication in the Hobbs Coast region is that the volcanism occurred on interfluves between regions of fast-flowing ice. Such a setting precludes establishing precise regional paleo-ice-levels although the presence or absence of ice at times of eruptions can be inferred.
\end{abstract}

Citation: Wilch, T. I., and W. C. McIntosh (2007), Miocene-Pliocene ice-volcano interactions at monogenetic volcanoes near Hobbs Coast, Marie Byrd Land, Antarctica, in Antarctica: A Keystone in a Changing World-- Online Proceedings of the $10^{\text {th }}$ ISAES, edited by A. K. Cooper and C. R. Raymond, USGS Open-File Report 2007-1047, Short Research Paper 074, 7 p.; doi:10.3133/of2007-1047.srp074

\section{Introduction}

Volcanism and glaciation have been active geological forces in Marie Byrd Land since middle Cenozoic time (Wilch and McIntosh, 2002). The Marie Byrd Land Volcanic Province consists of about 50 middle to late Cenozoic alkaline volcanic centers, including nineteen large, polygenetic volcanoes (2364-4181 m above sea level), exposed as nunataks in the marine-based West Antarctic Ice Sheet (WAIS). Many of the volcanoes preserve records of syn-eruptive interactions with ice that can be used to infer paleo-ice-levels of the WAIS. LeMasurier (1972) pioneered the use of volcanic records to infer glacial history in West Antarctica, based on regional reconnaissance field work and $\mathrm{K} / \mathrm{Ar}$ geochronology. The premise of the volcanological approach is that when volcanoes erupt below, at, or above the level of an ice sheet, the resulting rocks exhibit specific textural features and structures that are diagnostic of their eruptive environments. Subglacially erupted rocks imply local paleo-ice-levels higher than the outcrops; subaerially erupted rocks imply local paleo-ice-levels lower than the outcrops. Thus, records of the age and eruptive environment of volcanic rocks provide snapshot views of the syn-eruptive levels of the ice sheet at each outcrop locality.

Our study combines new ${ }^{40} \mathrm{Ar} /{ }^{39} \mathrm{Ar}$ dating and detailed field work to reconstruct a volcanic record of the WAIS in the Hobbs Coast region, building upon previous work (see summary in LeMasurier et al., 1990). There are seven volcanic nunataks located on the east side of the Berry Glacier trough (Figure 1). The Miocene-Pliocene volcanic deposits overlie basement rocks on what appear to be uplifted horst blocks adjacent to the downdropped, glacier-filled graben troughs. The regional significance of the paleo-ice-levels is complicated by the fact that many of these volcanoes are located on glacial interfluves. In general, our interpretations differ significantly from previous interpretations and suggest that there is abundant evidence for ice-volcano interactions but limited evidence of higher-than-present syn-eruptive ice-levels.

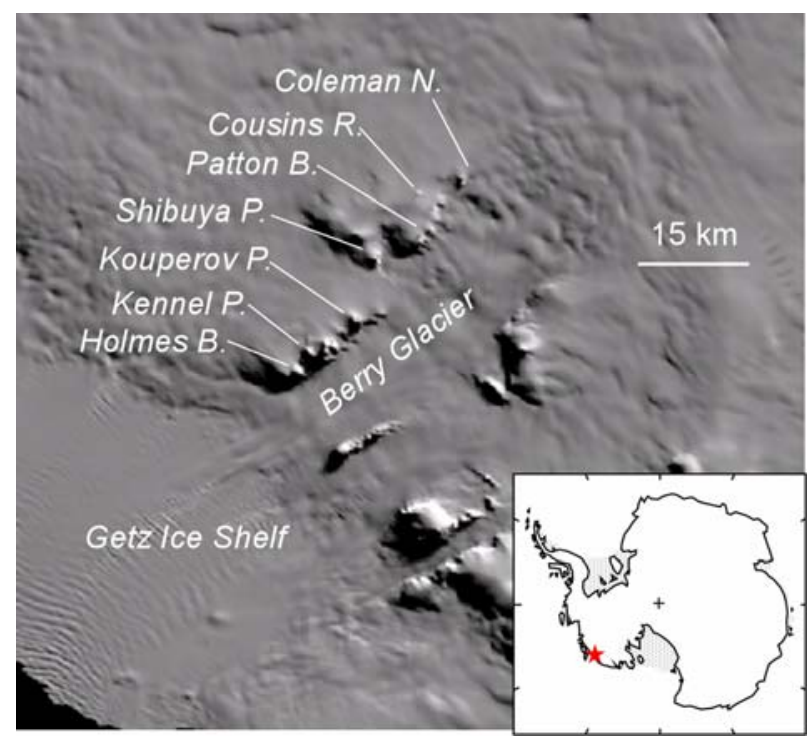

Figure 1. Satellite image map of Hobbs Coast nunatak study area. Image from Modis Mosaic of Antarctica (Haran, et al., 2005; http://planet.sr.unh.edu/MOA/).

\section{${ }^{40} \mathrm{Ar} /{ }^{39} \mathrm{Ar}$ geochronology}

Twenty-one mafic to intermediate alkaline volcanic rocks were dated by the ${ }^{40} \mathrm{Ar} /{ }^{39} \mathrm{Ar}$ resistance-furnace incremental heating method at the New Mexico Geochronology Research Laboratory at the New Mexico Institute of Mining and Technology, Socorro, NM. Sample preparation and analyses were conducted according to methods described in Wilch et al. (1999). Groundmass concentrates from all twenty-one samples and plagioclase phenocrysts from two samples were 
analyzed and plotted on age spectrum and isochron diagrams. Table 1 summarizes the dating results; complete data are available at NM open-file report (Wilch and McIntosh, in press).

Table 1. ${ }^{40} \mathrm{Ar} /{ }^{39} \mathrm{Ar}$ Dating Results

\begin{tabular}{|c|c|c|c|}
\hline $\begin{array}{l}\text { Sample } \\
\text { WCM93- }\end{array}$ & MSWD & $\begin{array}{c}\text { Best } \\
\text { Age } \pm 2 \text { s.d. }\end{array}$ & $\begin{array}{c}\text { Notes } \\
\text { (Rock Type) }\end{array}$ \\
\hline \multicolumn{4}{|c|}{ Coleman Nunatak } \\
\hline 199 & 1.5 & $2.55 \pm 0.06$ & S.end, lava (bn) \\
\hline 185 & 0.2 & $2.62 \pm 0.28$ & S. end, lava (hw) \\
\hline 184 & 0.0 & $2.68 \pm 0.14$ & S. end, lava (bn) \\
\hline 192 & 0.8 & $2.59 \pm 0.20$ & S. end, lava( bn) \\
\hline 190 & 2.1 & $3.37 \pm 0.25^{1}$ & S. end, lava (bn) \\
\hline 198 & 3.9 & $7.30 \pm 0.72^{1}$ & S. end, bomb (bn) \\
\hline 188 & 2.3 & $2.47 \pm 0.12$ & S. end, lava (bn) \\
\hline 208 & 5.8 & $2.57 \pm 0.12$ & N. end, clast (bn) \\
\hline 207 & 3.4 & $2.60 \pm 0.09$ & N. end, dike (bn) \\
\hline 205 & 0.5 & $2.77 \pm 0.27$ & N. end, dike(bn) \\
\hline \multirow{2}{*}{202} & 2.0 & $2.82 \pm 0.23$ & N. end, dike (bn) \\
\hline & 1.6 & $2.58 \pm 0.05$ & Mean $(n=9)$ \\
\hline \multicolumn{4}{|c|}{ Cousins Rock } \\
\hline 218 & 2.8 & $4.89 \pm 0.10$ & bomb (pt) \\
\hline \multirow[t]{2}{*}{219} & 1.5 & $4.99 \pm 0.04^{2}$ & lava (pt) \\
\hline & 3.3 & $4.97 \pm 0.07$ & Mean $(n=2)$ \\
\hline \multicolumn{4}{|c|}{ Shibuya Peak } \\
\hline 221 & 0.8 & $5.09 \pm 0.12$ & bomb (hw) \\
\hline 223 & 1.3 & $5.32 \pm 0.20$ & lava crusts (hw) \\
\hline \multirow[t]{2}{*}{229} & 2.0 & $4.78 \pm 0.11$ & dike (hw) \\
\hline & 14.5 & $4.97 \pm 0.28$ & Mean $(n=3)$ \\
\hline \multicolumn{4}{|c|}{ Patton Bluff } \\
\hline 307 & 3.8 & $11.38 \pm 0.23^{2}$ & lava (bs) \\
\hline \multicolumn{4}{|c|}{ Kouperov Peak } \\
\hline 303 & 1.6 & $9.26 \pm 0.58^{3}$ & lava (bs) \\
\hline 303 & 3.4 & $9.58 \pm 0.36$ & lava (bs(p)) \\
\hline 304 & 1.3 & $9.02 \pm 0.49^{4}$ & lava (bs) \\
\hline \multirow[t]{2}{*}{304} & 1.7 & $8.99 \pm 0.31$ & lava (bs(p)) \\
\hline & 2.3 & $9.21 \pm 0.30$ & Mean $(n=4)$ \\
\hline \multicolumn{4}{|c|}{ Kennel Peak } \\
\hline 299 & 62.4 & $7.96 \pm 0.87^{2}$ & pillow (hw) \\
\hline \multicolumn{4}{|c|}{ Holmes Bluff } \\
\hline 292 & 0.5 & $6.32 \pm 0.07$ & lava (bn) \\
\hline
\end{tabular}

Notes: ${ }^{1}$ Inaccurate age determination, not used in mean age. ${ }^{2}$ Weighted mean age. ${ }^{3}$ isochron age; ${ }^{40} \mathrm{Ar} /{ }^{36} \mathrm{Ar}=$ $301 \pm 2$. ${ }^{4}$ isochron age, ${ }^{40} \mathrm{Ar} /{ }^{36} \mathrm{Ar}=300 \pm 3$; Rock type: bs: basanite, bs(p): plagioclase in basanite; bs: basalt; hw: hawaiite; pt: phonotephrite (from Wilch, 1997).

Most step-heating analyses yielded relatively flat age spectra for which plateau ages (weighted mean of three or more steps that differ by $<2$ sigma) are interpreted as the best estimates of eruption age. In a few cases, where age spectra were slightly more disturbed, weighted-mean ages were calculated for select steps that approached but failed to meet plateau criteria. In two cases, where the ${ }^{40} \mathrm{Ar} /{ }^{36} \mathrm{Ar}$ isochron intercept exceeded 295.5, isochron intercept ages were selected as the best estimates of eruption age. Two samples (Table 1) yielded disturbed age spectra and poorly correlated isochrons that precluded accurate determinations of eruptions age. For each locality, a weighted mean age was calculated by pooling all available analyses. In all cases where multiple samples from one locality were dated, the narrow range of ages, combined with stratigraphic and geochemical data, suggests a brief monogenetic eruptive history, as opposed to extended or polygenetic activity, as further discussed below. The seven dated volcanic centers ages range from $11.38 \pm 0.23$ to $2.58 \pm 0.12 \mathrm{Ma}$.

\section{Volcanic lithofacies analysis}

Recent Antarctic field-based lithofacies studies have led to major advances in reconstruction of paleoenvironments associated with ice-volcano interactions (e.g., Smellie, 2001; Wilch and McIntosh, 2000, 2002). In lithofacies analysis, paleoenvironmental interpretations are built upon detailed, field-based, nongenetic descriptions of rock units and their relationships to one another. Non-genetic volcanic lithofacies designations are typically based on rock type (lava or clastic), grain size, sedimentary structures and clast characteristics (morphology, vesicularity, componentry) (following McPhie et al., 1993). Depositional processes and environments are interpreted by comparison of features of lithofacies and lithofacies assemblages to modern analogues. In many volcanological studies, partly genetic lithofacies designations that define the original clast-forming mechanism, such as pyroclastic or autoclastic, are used along with non-genetic designations (e.g., Sohn, 1996). The mixing of genetic and nongenetic terminology in the description of volcanic sequences has led to some confusion.

In previous reconnaissance studies (e.g. LeMasurier et al., 1990), the term hyaloclastite was broadly defined as a fracture-bounded, glassy, fragmental rock, which included other forms of palagonitized fragmental rock. The definition of hyaloclastite included a distinct genetic interpretation as an indicator of subglacial environments and higher paleo-ice-levels. This broad definition of hyaloclastite has two major weaknesses. First, the definition does not differentiate clasts produced by passive granulation in a subaqueous setting from those produced by hydromagmatic explosivity in an emergent to subaerial environment. Second, palagonite is a product of hydration and alteration of quenched sideromelane glass and is common in a variety of hydrovolcanic environments ranging from deep subaqueous to emergent to subaerial (see review by Stroncik and Schmincke, 2002). Palagonitized deposits have also been identified in dry, strombolian subaerial volcanoes, where they are attributed to post-eruptive alteration by steam or 

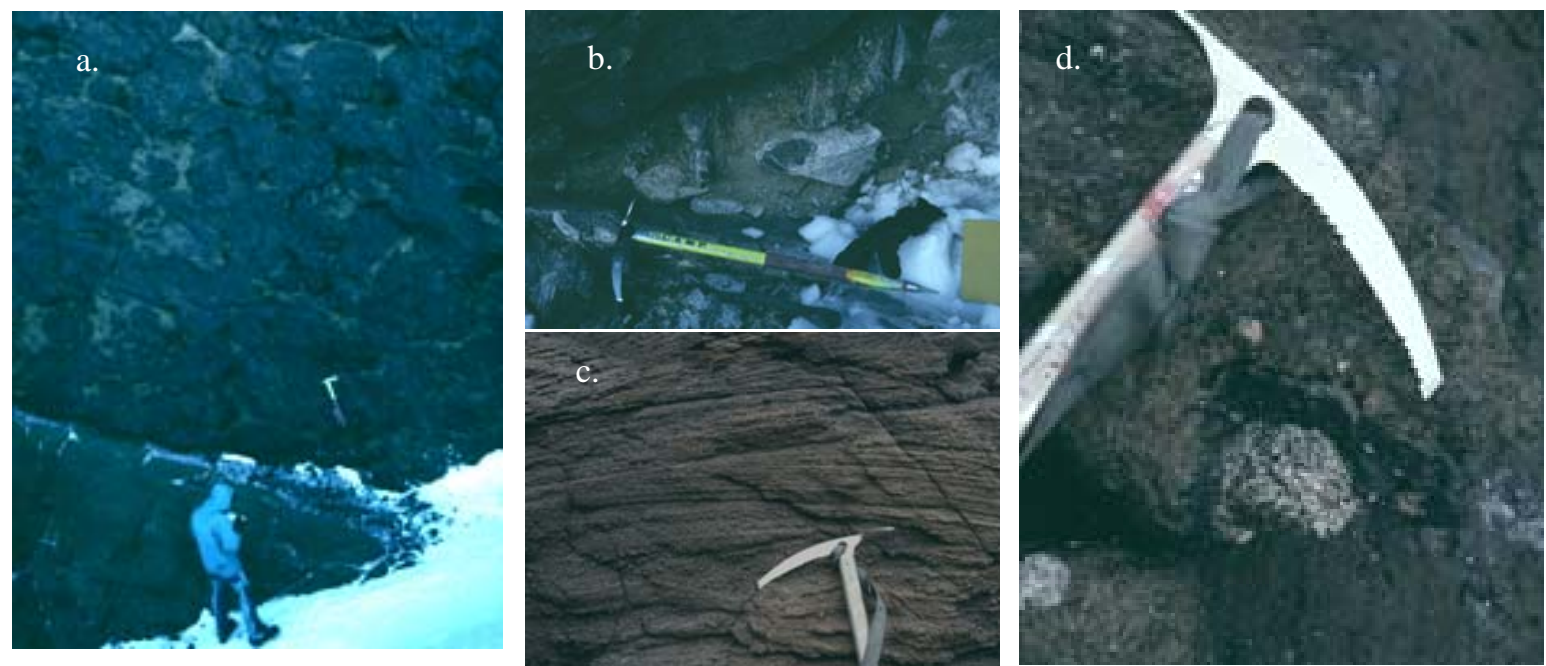

Figure 2. Field photos: a. Nested pillow lava at Kennel Peak. b.Glacial till beneath pillow lava at Kennel Peak. c. Crossbedded palagonitized lapilli tuff at Coleman Nunatak wind moat. d. Lava encrusted granite cobble at Shibuya Peak.

surface water (e.g., Houghton and Schmincke, 1986; LeMasurier et al., 1994). The broad usage of the term hyaloclastite in previous studies led to an overestimation of the number of subglacial volcanic deposits and higherthan-present paleo-ice-levels.

In this paper, the term hyaloclastite is used exclusively as a genetic (i.e. interpretive) term rather than a nongenetic (descriptive) term. The term hyaloclastite is restricted to glassy breccia generated by passive granulation of lava in a subaqueous environment. The term vitric (glassy) tuff is used to describe glassy volcanic sediments generated by hydromagmatic explosions. Many previously reported subglacial hyaloclastites in the Hobbs Coast area are re-interpreted in this paper as pyroclastic rocks derived from emergent to subaerial eruptions.

We interpret outcrops as recording former subaqueous/subglacial, emergent, or subaerial paleoenvironments. Subaqueous/subglacial environments are evidenced by the following lithofacies assemblage: pillow lava associated with fines-poor, blocky, glassy breccias, erosional unconformities, and tillites. Emergent environments are indicated by vitric tuffs, with moderately vesiculated sideromelane- and tachylite-rich clasts, armored lapilli, abundant lithic clasts, bedding plane sags, and planar and cross-bedded strata. Subaerial environments are indicated by lava, breccia, and agglutinate with fluidal and welded textures, red deuteric oxidation, and no or little evidence of water-magma interaction. Some outcrops exhibit evidence of more than one paleoenvironment. The geology of each nunatak is presented below.

\section{Subglacial paleoenvironments}

A subglacial paleoenvironment is interpreted at Kennel Peak based on a previously undescribed $\sim 125 \mathrm{~m}$ thick rock exposure in a deep wind moat on the east side of the nunatak. The stratigraphic sequence is composed of granitic basement rocks unconformably overlain by a $<1 \mathrm{~m}$ thick diamict and $\sim 125 \mathrm{~m}$ thick hawaiitic pillow lavas and interpillow hyaloclastite breccia (Figure 2a-b). The pre-volcanic unconformity has a molded appearance and is situated approximately $100 \mathrm{~m}$ lower than the level of the local ice surface. The diamict is a weakly cemented, poorly sorted, bouldery gravelly mud. Boulder clasts are subangular and appear to be composed of local bedrock; gravel clasts are subrounded to subangular, molded and faceted and are composed of plutonic and metamorphic basement lithologies and laminated mudstone clasts. The overlying volcanic sequence comprises a well exposed pillow lava/hyaloclastite breccia sequence. The $\sim 125 \mathrm{~m}$ thick section consists of very crudely bedded, steeply dipping $\left(15-30^{\circ}\right)$ pillow lavas and interpillow hyaloclastite breccia. The pillow sequence is interrupted by an unconformity, which is overlain by a planar stratified, crudely graded pebble hyaloclastite.

The pillow lavas and hyaloclastites at Kennel Peak are inferred to have been deposited in a subglacial chamber onto thin basal till and glacially molded bedrock. The vesicularity and steep dips of the interbedded pillow lava and hyaloclastite, and the presence of similar age subaerial lava flows elsewhere at Kennel Peak (LeMasurier et al., 1990) suggest that the deposits form part of a subaqueous flow-foot delta sequence, possibly associated with subaerial lava effusion. The pillow lava and hyaloclastite sequence extend only $\sim 25 \mathrm{~m}$ above today's ice surface, suggesting that the syn-eruptive local paleo-ice-level was at least slightly higher than today's ice level. A weighted mean age $7.96 \pm 0.87 \mathrm{Ma}$ was obtained from one sample of pillow lava at Kennel Peak. 


\section{Emergent to subaerial paleoenvironments}

Coleman Nunatak is an approximately $1 \times 3 \mathrm{~km}$ basaltic nunatak that has a gently undulating top surface just above the level of the ice sheet, with a small peak at the north end and a $75 \mathrm{~m}$ deep, $1 \mathrm{~km}$ long wind moat at the south end. Volcaniclastic deposits in the wind moat are dominated by alternating packages of poorly sorted, crudely stratified to massive, thick beds $(\sim 1 \mathrm{~m})$ of coarse vitric lapillistone, and well-stratified, moderately sorted, thin beds $(0.5-5 \mathrm{~cm})$ of medium vitric lapilli tuff (Figure 3). Individual beds can be traced for only short distances $(<4 \mathrm{~m})$ whereas bed packages are traceable for $>50 \mathrm{~m}$. The beds are typically plane parallel, with rare low-angle cross stratification and crude normal and reverse grading (Figure 2c). Smaller clasts $(<1 \mathrm{~cm})$ tend to be subrounded, highly vesicular tachylite, whereas larger clasts tend to be subangular, poorly vesicular holocrystalline basanite. Mud-coated lapilli clasts and reddened, breadcrusttextured pyroclastic bombs (to $25 \mathrm{~cm}$ ) associated with bedding plane sags occur locally. The alternating units interfinger with scoriaceous lapillistone and tuff breccia that contains reddened pyroclastic bombs. The combination of scoriaceous pyroclastic lithofacies and well bedded lapilli tuff with armored lapilli and asymmetric bedding plane sags suggest these deposits were formed by mixed hydromagmatic and magmatic

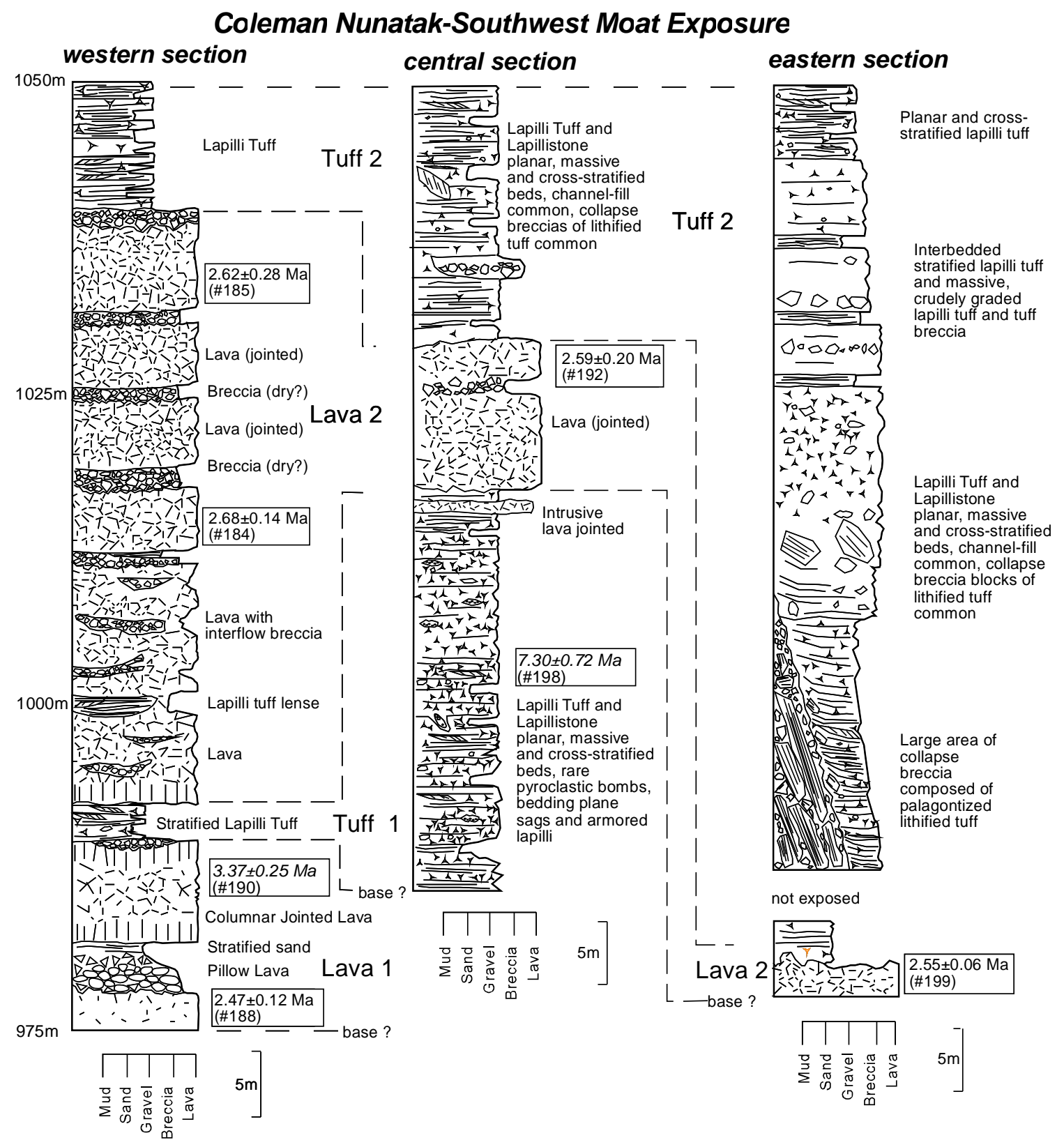

Figure 3. Three stratigraphic sections in wind moat at south end of Coleman Nunatak. Lavas can be traced from one section to the next. ${ }^{40} \mathrm{Ar} /{ }^{39} \mathrm{Ar}$ ages ( \pm 2 s.d.) are in boxes; rejected ages are in italics. 
fragmentation processes. The discontinuous, erosive, massive, planar, and cross-stratified beds are suggestive of base-surge deposits (Fisher and Schmincke, 1984). A 40x60 m area of meso-breccia is situated near the base of the eastern moat section. The meso-breccias are composed of up to $5 \mathrm{~m}$ diameter blocks of lithified, well bedded palagonitized vitric tuff. Lapilli clasts in the vitric tuff blocks resemble the dominant finely vesicular scoriaceous lapilli of the upper and lower tuff units.

The hydrovolcanic tuff and strombolian units are intercalated with compound lava flows that are slightly glassy, and highly jointed. The top of the lowest lava flow grades into pillow lava and hyaloclastite breccia. The minor pillow lava, hyaloclastite breccia and glassy textures all suggest subaqueous depositional environments. The combination of base-surge deposits and minor subaqueous lavas is indicative of an emergent intraglacial environment, where interaction with meltwater controlled the explosive hydromagmatic eruption style, and modified the lava flows slightly.

Steeply dipping massive to deformed vitric tuff is separated from underlying subhorizontally stratified to deformed vitric tuff by a prominent, steeply southward dipping angular unconformity. Several irregular intrusive lava apophyses cut across the pyroclastic rock exposures and are loci of soft sediment deformation. The stratified vitric tuff resembles stratified sequences in the moat section, described above. This section is interpreted as an eroded tuff cone vent, dominated by base-surge deposits at lower levels, that are cut by a "vent-funnel" unconformity and overlain by vent-slurry vitric tuff (as in Kokelaar, 1983).

${ }^{40} \mathrm{Ar} /{ }^{39} \mathrm{Ar}$ geochronologic results from Coleman Nunatak differ significantly from previously published KAr results and have implications for petrologic models as well as the glaciovolcanic history of Marie Byrd Land. A wide range of previous $\mathrm{K} / \mathrm{Ar}$ ages, 11.7 to $2.5 \mathrm{Ma}$, was interpreted as an indication of long-lived volcanism at Coleman Nunatak (LeMasurier et al., 1990; Hart et al., 1997). Detailed sampling $(n=11)$ and high precision ${ }^{40} \mathrm{Ar} /{ }^{39} \mathrm{Ar}$ ages suggest that the volcanism was monogenetic and occurred at $2.58 \pm 0.05 \mathrm{Ma}$. Five of seven samples from the moat sequence of lavas and tuffs at the south end of Coleman Nunatak and all four samples from the tuff cone sequence at the north end yielded concordant ${ }^{40} \mathrm{Ar} /{ }^{39} \mathrm{Ar}$ ages near 2.6 Ma (Table 1). Two glassy pyroclastic bomb and block samples collected from tuff units yielded discordant age spectra and anomalous older ages that were rejected as inaccurate derterminations of eruption age. Hart et al. (1997) developed a complicated petrologic model to explain the lack of chemical and isotopic changes at Coleman Nunatak over the long time interval ( $8 \mathrm{Ma}$ ) suggested by $\mathrm{K} / \mathrm{Ar}$ ages. The ${ }^{40} \mathrm{Ar} /{ }^{39} \mathrm{Ar}$ ages combined with the geochemical data of Hart et al. (1997) suggest that Coleman Nunatak is a chemically homogeneous, monogenetic volcano.
Shibuya Peak features unusual volcaniclastic deposits with abundant exotic clasts exposed in a $>100 \mathrm{~m}$ thick section. Clasts in the basaltic volcaniclastic deposit are heterolithic: lithologies include basement-derived granitoid clasts, crystal-rich intermediate lava, crystalpoor gray holocrystalline basaltic lava, pyroxenite xenoliths, and highly vesicular, sometimes oxidized basaltic cinders. The granitoid clasts (up to $1 \mathrm{~m}$ diameter) are commonly subrounded with a faceted or bullet-shaped appearance. Some granitoid cobbles are encrusted with a thin $(1 \mathrm{~cm})$ coat of basaltic lava (Figure 2d). The volcaniclastic deposits include a variety of sedimentary structures, ranging from massive to subhorizontal (4-10*) stratification and cross-stratification, local reverse and normal grading, variable sorting with abundant outsized clasts, heterolithic clasts and matrix with an even mixture of sideromelane and tachylite glass, blocky but not particularly glassy lava lithic clasts, and variably vesicular cinders.

The lithology and sedimentary structures in the volcaniclastic deposit are consistent with an emergent hydrovolcanic to subaerial strombolian eruptive environment. Although the stratigraphic section was previously described as "bedded basaltic hyaloclastite" with "interbedded tillite" and interpreted as evidence for a subglacial eruptive environment (LeMasurier, 1990), the volcaniclastic material does not appear to be a hyaloclastite, as defined in this paper. The presence of granitoid erratics and other exotic clasts within the volcaniclastic deposit, some with glacial forms and some encrusted in juvenile lava, suggest that the volcanic deposits were erupted through glacial sediment. The encrustation of erratics by lava is consistent with eruption through a tillite but not consistent with the clasts being part of an interbedded glacial tillite. The ages of the three dated samples at Shibuya Peak nearly overlap at 2 sigma, and yield a weighted mean ${ }^{40} \mathrm{Ar} /{ }^{39} \mathrm{Ar}$ age of $4.97 \pm 0.28$ Ma.

At Holmes Bluff, a $\sim 55 \mathrm{~m}$ thick, columnar-jointed, valley-filling lava flow with a $1.3 \mathrm{~m}$ thick basal breccia overlies a $1.5 \mathrm{~m}$ thick lapilli tuff and a partially molded basement unconformity. The upper surface of the basement unconformity exhibits areas of weathered, irregular vertical joint blocks and areas of surface molding without striations. The lapilli tuff is weakly welded, crudely stratified, well- sorted, and dominated by moderately to highly vesicular sideromelane grains with fluidal droplet textures. The valley-filling lava is massive, with radiating columnar-joints (perpendicular to paleovalley walls). The base of the lava is a 1-3 m thick welded breccia and the top is characterized by a ropey, brecciated surface. The sequence is tentatively interpreted as a basement glacial unconformity that was subsequently exposed and locally weathered before being covered by a thin, subaerially erupted, pyroclastic fall deposit and a thick, valley-filling, subaerial lava. The single dated 
sample from Holmes Bluff yielded a plateau ${ }^{40} \mathrm{Ar} /{ }^{39} \mathrm{Ar}$ age of $6.32 \pm 0.07 \mathrm{Ma}$.

A massive, crystal-rich basaltic lava unconformably overlies basement rocks at the south end of Kouperov Peak. The unbrecciated lava is about $30 \mathrm{~m}$ above the present ice surface. The lava/basement contact is poorly exposed but extends over $>60 \mathrm{~m}$ of topographic relief. The basement rocks are locally striated to within $2 \mathrm{~m}$ of the lava, although no striations were observed beneath the lava. This surface is tentatively interpreted as a glacial unconformity overlain by subaerial lava. Groundmass and plagioclase results from two samples from Kouperov Peak yield a weighed mean ${ }^{40} \mathrm{Ar} /{ }^{39} \mathrm{Ar}$ age of $9.21 \pm 0.30$ Ma.

Cousins Rock is a small $(150 \times 150 \mathrm{~m})$ nunatak that consists mostly of oxidized phonotephrite and welded agglutinate. The agglutinate is composed of welded, highly vesicular, tachylite lapilli grains. A palagonitized, bedded, matrix- to clast-supported fines-rich subrounded vesicular sideromelane sandy diamictite occurs as a separate smaller outcrop just west of the main outcrop. The diamictite is interpreted as a phreatomagmatic vitric tuff associated with a wet base surge eruption. The lava and agglutinate are interpreted as spatter-fed deposits associated with a subaerial, strombolian style eruption. Two dated samples from Cousins Rock yielded a weighted mean ${ }^{40} \mathrm{Ar} /{ }^{39} \mathrm{Ar}$ age of $4.97 \pm 0.07 \mathrm{Ma}$.

A massive, crystal-rich basaltic lava appears to overlie basement rocks at Patton Bluff, although the unconformable contact is not exposed. The basement rocks and the lava are both locally striated. The lava is interpreted as subaerial in nature, offering no evidence for syneruptive glaciation at the time of the eruption. A single sample from Patton Bluff yielded a plateau ${ }^{40} \mathrm{Ar}{ }^{39} \mathrm{Ar}$ age of $11.38 \pm 0.23 \mathrm{Ma}$.

\section{Discussion}

The Hobbs Coast nunataks exhibit evidence consistent with locally variable syneruptive ice levels in late Miocene-Pliocene times. Interpreting the volcanic record in terms of WAIS history is not straightforward. Small volcanoes perched on interfluves between areas of faster flowing ice may exhibit records of changing local ice levels that give false impressions of the magnitude and elevations of regional ice level variations (Figures 1 and 4). Regional growth of the ice sheet may not cause higher ice levels at these nunataks if the local ice streams compensate by discharging ice at a greater rate. In addition, uncertainties about the timing of downcutting of the adjacent drainages weaken interpretations of regional paleo-ice-level in all cases.

The record of an approximately $25 \mathrm{~m}$ higher local ice level at Kennel Peak may indicate a slightly higher regional ice level at $7.96 \pm 0.87 \mathrm{Ma}$. Alternatively, this small apparent change in ice level may reflect local downcutting adjacent to Kennel peak. The emergent to

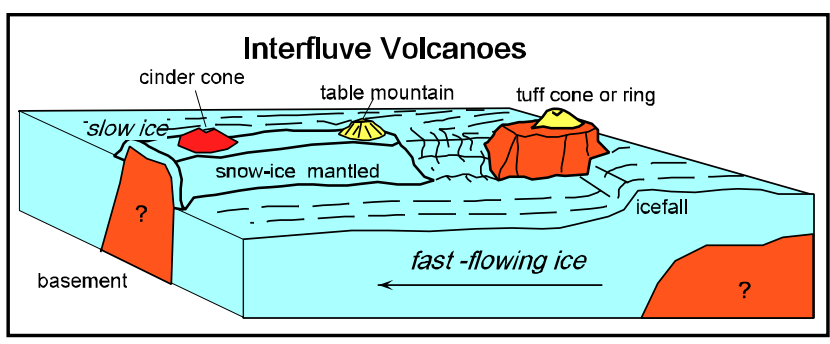

Figure 4. Cartoon of volcanoes on glacial interfluve. Bedrock is orange colored, volcanoes red and yellow. Berry Glacier (Fig. 1) represents fast-flowing ice.

subaerial lithofacies at the other Hobbs Coast sites are generally consistent with regional ice levels similar to the current WAIS during brief eruptive periods ranging from 11.4 to $2.6 \mathrm{Ma}$, although this interpretation is somewhat compromised by their positions on glacial interfluves. None of the Hobbs Coast Nunataks provide compelling evidence for regional paleo-ice-levels considerably higher than the current WAIS.

Acknowledgments. This work was supported by NSF grant. We thank co-editor Paul Fitzgerald, and reviewers Ben Edwards, and Brenda Hall for helpful comments on the manuscript, Nelia Dunbar for insights and assistance in the field, Tony Teeling for mountaineering support, US Navy VXE-6 and Ken Borek and Associates for air-support, and Rich Esser and Lisa Peters for assistance with geochronology.

\section{References}

Fisher, R. V., and H. Schmincke (1984), Pyroclastic rocks, 472 pp., Springer-Verlag, Berlin.

Haran, T., et al. (2005), MODIS mosaic of Antarctica (MOA) image map. Boulder, CO, USA: National Snow and Ice Data Center. Digital media.

Hart, S. R., et al. (1997), Hobbs Coast Cenozoic volcanism: Implications for the West Antarctic Rift System, Chem. Geol., 139, 223-248.

Houghton, B. F., and H.-U. Schmincke (1986), Mixed deposits of simultaneous strombolian and phreatomagmatic volcanism: Rothenberg volcano, East Eifel volcanic field, J. Volcanol. Geoth. Res., 30, 117-130.

Kokelaar, B. P. (1983), The mechanism of surtseyan volcanism, J. Geol. Soc. London, 140, 939-944.

LeMasurier, W. E. (1972), Volcanic record of Cenozoic glacial history in Marie Byrd Land, in Antarctic Geology and Geophysics, edited by R. J. Adie, pp. 251-260, Universitetsforlaget, Oslo.

LeMasurier, W. E., et al. (1994), Geology of Mount Murphy Volcano: An 8-m.y. history of interaction between a rift volcano and the West Antarctic ice sheet, Geol. Soc. Am. Bull., 106, 265-280.

LeMasurier, W. E., et al. (1990), Miocene-Pliocene centers, Hobbs Coast, in Volcanoes of the Antarctic Plate and Southern Oceans, edited by W. E. LeMasurier and J. W. Thomson, pp. 244-247, AGU, Washington, D.C.

McPhie, J., et al. (1993), Volcanic textures: a guide to the interpretation of textures in volcanic rocks, 198 pp., Centre for Ore Deposit and Exploration Studies, University of Tasmania, Hobart, Tasmania.

Smellie, J. L. (2001), Lithofacies architecture and construction of volcanoes erupted in englacial lakes; Icefall Nunatak, Mount Murphy, eastern Marie Byrd Land, Antarctica, in Volcaniclastic sedimentation in lacustrine settings, edited by N. R. Riggs and J. D. L. White, pp. 934, Blackwell Science, Malden, MA.

Sohn, Y. K. (1996), Hydrovolcanic processes forming basaltic tuff rings and cones on Cheju Island, Korea, Geol. Soc. Am. Bull., 108, 11991211.

Stroncik, N. A., and H.-U. Schmincke (2002), Palagonite- a review, Int. J. Earth Sci., 91, 680-697. 
Wilch, T. I. (1997), Volcanic record of the West Antarctic Ice Sheet in Mare Byrd Land, Ph.D. thesis, New Mexico Institute of Mining and Technology, Socorro, NM.

Wilch, T. I., and W. C. McIntosh (2000), Eocene and Oligocene volcanism at Mt. Petras, Marie Byrd Land: implication s for middle Cenozoic ice sheet reconstructions in West Antarctica, Antarc. Sci., 12, 477-491.

Wilch, T. I., and W. C. McIntosh (2002), Lithofacies analysis and ${ }^{40} \mathrm{Ar} /{ }^{39} \mathrm{Ar}$ geochronology of ice-volcano interactions at Mt. Murphy and the Crary Mountains, Marie Byrd Land, Antarctica: implications for Late Miocene ice-sheet history in West Antarctica, in Ice-volcano Interaction on Earth and Mars, edited by J. L. Smellie and M. R. Chapman, pp. 237-253, Geological Society of London, London, U.K.

Wilch, T. I., and W. C. McIntosh (in press), ${ }^{40} \mathrm{Ar} /{ }^{39} \mathrm{Ar}$ geochronological data from Hobbs Coast nunataks, Antarctica, New Mexico Bureau of Geology and Mineral Resources, Open-File Report.

Wilch, T. I., et al. (1999), Late Quaternary Volcanic Activity in Marie Byrd Land: Potential ${ }^{40} \mathrm{Ar} /{ }^{39} \mathrm{Ar}$-dated time horizons in West Antarctic ice and marine cores, Geol. Soc. Am. Bull., 111, 1563-1580. 